\title{
Do mediterranean genera not included in Tachet et al. 2002 have mediterranean trait characteristics?
}

\author{
Núria Bonada ${ }^{1, *}$ and Sylvain Dolédec ${ }^{2}$
}

${ }^{1}$ Grup de Recerca "Freshwater Ecology and Management" (FEM), Departament d'Ecologia, Facultat de Biologia, Universitat de Barcelona, Diagonal 645, 08028 Barcelona, Catalonia/Spain.

${ }^{2}$ UMR CNRS 5022 Lehna, Biodiversité des Ecosystèmes Lotiques, Université Lyon 1, F-69622 Villeurbanne, France.

* Corresponding author: bonada@ub.edu

Received: $18 / 3 / 10 \quad$ Accepted: $21 / 3 / 11$

\begin{abstract}
Do mediterranean genera not included in Tachet et al. 2002 have mediterranean trait characteristics?

Multiple-trait databases are increasingly used in community ecology in different regions of the world. In Europe, Tachet $e t$ al. (2002) compiled an aquatic macroinvertebrate database for 473 taxa using information on 11 biological traits described by 63 categories. However, less studied regions, at the time of the compilation of the database, such as the mediterranean Basin, can harbour exclusive genera, which were not included in Tachet's database. In a large-scale study across the mediterranean Basin, we found 44 genera that were not included in Tachet's database (NEW genera). Our main aim was to compile trait information for these NEW genera and assess whether these genera had specific traits that could explain their exclusivity to the Mediterranean region. We compared the trait characteristics of NEW genera to those of genera only found in Mediterranean or temperate regions that were included in the Tachet's database (MED and TEM genera, respectively). We found that NEW genera had more mediterranean characteristics than TEM genera and that some trait categories of NEW genera were even more mediterranean-like than the traits of MED genera (e.g., diapause). Therefore, our results suggest that the specific biological traits of these NEW genera allow them to cope successfully and exclusively with the harsh environmental conditions of the mediterranean climate rivers, which could partially explain their absence in Tachet's database. Other explanations, such as the limited dispersal ability of these NEW genera to reach and colonize temperate Europe or the rarity of these NEW genera, should also be considered. We provide biological traits of the NEW genera to be used in future studies on the mediterranean river ecology.
\end{abstract}

Key words: Aquatic macroinvertebrates, biological traits, fuzzy coding, Mediterranean Basin, temperate Europe.

\section{RESUMEN}

¿Los géneros mediterráneos no incluidos en la Tachet et al. (2002) presentan rasgos típicamente mediterráneos?

Las bases de datos de múltiples rasgos biologicos están siendo cada vez más utilizadas en ecología de comunidades en distintas regiones del mundo. En Europa, Tachet et al. (2002) recopilaron información de macroinvertebrados acuáticos para 473 taxones de 11 rasgos biológicos que incluyen 63 categorías. No obstante, es esperable que las regiones menos estudiadas durante la recopilación de datos, tales como las mediterráneas, alberguen géneros exclusivos que por falta de información no fueron incluidos inicialmente en la base de datos de Tachet. En un estudio a lo largo de la cuenca mediterránea, se encontraron 44 géneros no incluidos en la base de datos de Tachet (géneros NEW). Nuestro principal objetivo fue recoger información de estos géneros y analizar si tenían rasgos mediterráneos específicos que pudieran explicar su exclusividad en estos ambientes. Así, comparamos los rasgos de los géneros NEW con aquellos géneros encontrados en las regiones mediterráneas y templadas incluidos en la base de datos de Tachet (géneros MED y TEM, respectivamente). Los resultados mostraron que los géneros NEW tenían rasgos más mediterráneos que los géneros TEM, y que algunos de ellos incluso lo eran más que los de los géneros MED (e.g. diapausa). Por lo tanto, nuestros resultados sugieren que los rasgos específicos de estos géneros NEW les permiten hacer frente a las condiciones ambientales que caracterizan los ríos mediterráneos, lo que podría explicar, en parte, su ausencia en la base de datos de Tachet. Asimismo, se han considerado otras razones, tales como 
la limitada dispersión de estos géneros NEW para colonizar la Europa templada o su rareza. Se proporcionan los rasgos biológicos de estos géneros $N E W$ para ser utilizados en futuros estudios en ríos de clima mediterráneo.

Palabras clave: Macroinvertebrados acuáticos, rasgos biologicos, codificación difusa, cuenca mediterránea, Europa templada.

\section{INTRODUCTION}

Biological traits are individual attributes that determine the presence of species in particular habitats and the ability of species to interact with other species. Considered both a product of the ecology (sorting) and the evolutionary history of species, traits have been utilised in many fields, including community ecology, molecular phylogenetics and biodiversity conservation (Statzner et al., 2001; Macleod \& Forey, 2002; CavenderBares et al., 2004; Henry et al., 2008). Multipletrait databases are available for a wide variety of taxa, although plants are clearly the organisms that have had more attention (Kühn et al., 2004). For freshwater macroinvertebrates, there are currently five main databases that include many genera present in Europe (Tachet et al., 2002), North America (Bêche et al., 2006; Vieira et al., 2006), South-America (Tomanova \& Usseglio-Polatera, 2007) and New Zealand (Dolédec et al., 2006). Studies dealing with these databases have analysed trait responses to several environmental gradients, including natural disturbance, pollution, and hydrological or latitudinal aspects (Statzner et al., 2005; Bêche et al., 2006; Bonada et al., 2007b; Horrigan \& Baird, 2008). Scientists agree that the use of traits offers a great opportunity to understand how the functional role of freshwater macroinvertebrate communities is constrained by the environment.

For France, Belgium and Pyrénées, the database of Tachet et al. (hereafter Tachet's database) specifically comprises 11 biological traits and 63 categories that consider aspects related to the morphology, behaviour, life history and physiology of freshwater macroinvertebrates (Table 1) alongside 11 ecological traits that are described by 60 categories. For each taxon, these authors coded each trait category using a fuzzy coding approach (Chevenet et al., 1994), where a value of 0 indicates no affinity of the taxon for the trait category, 1 indicates low affinity, 2 indicates medium affinity and 3 or $>3$ indicates strong affinity. In contrast to a presence/absence approach, fuzzy coding provides semi-quantitative data and considers trait plasticity within genera or across space (i.e., a multivoltine species in the Mediterranean Basin can be semivoltine in Scandinavia). Tachet's database incorporates 473 taxa, mostly at the genus level (433), and the authors used information gathered from $\sim 6000$ published and unpublished studies. These studies cover a time period of more than one century - the first record in Tachet's database dates back to 1802 - and include all information collected in Europe until the publication of the database. Therefore, even though it only includes French, Belgium and Pyrenean genera, Tachet's database considers the expression of invertebrate biological traits from many European regions. However, exclusive genera from other European countries may not be present in the Tachet's database, and their biological traits need to be coded for better characterization of the functional characteristics in these countries.

Studying large scale responses of freshwater macroinvertebrates traits to natural disturbance, Statzner et al. (2007) and Bonada et al. (2007a; unpublished material) found several genera present in the Mediterranean Basin that were not included in the Tachet's database. Considering the increasing use of macroinvertebrate traits in freshwater studies, our main aim was to code these genera in a similar way as in Tachet's database and to make this information 
Table 1. Genus biological traits and categories from Tachet et al. (2002) with their associated codes. Predictions indicate whether the category proportion should be higher in the mediterranean than in the temperate region (M) or the contrary (T). The rationale behind each prediction can be found in Bonada et al. (2007). Géneros y categorías biológicas utilizadas en Tachet et al. (2002) con los correspondientes códigos. Las predictiones indican si la categoría debería tener una mayor proporción en la región mediterránea que en la templada $(M)$ o lo contrario $(T)$. La razón de cada predicción se describe en Bonada et al. (2007).

\begin{tabular}{|c|c|c|c|}
\hline Trait & Category & Code & Predictions \\
\hline Maximal size & $\begin{array}{l}\leq 0.25 \mathrm{~cm} \\
>0.25-0.5 \mathrm{~cm} \\
>0.5-1 \mathrm{~cm} \\
>1-2 \mathrm{~cm} \\
>2-4 \mathrm{~cm} \\
>4-8 \mathrm{~cm} \\
>8 \mathrm{~cm}\end{array}$ & $\begin{array}{l}\mathrm{a} 1 \\
\mathrm{a} 2 \\
\mathrm{a} 3 \\
\mathrm{a} 4 \\
\mathrm{a} 5 \\
\mathrm{a} 6 \\
\mathrm{a}\end{array}$ & $\begin{array}{c}\mathrm{M} \\
\mathrm{M} \\
\mathrm{T} \\
\mathrm{T} \\
\mathrm{M} \\
\mathrm{M}\end{array}$ \\
\hline Life cycle duration & $\begin{array}{l}\leq 1 \text { year } \\
>1 \text { year }\end{array}$ & $\begin{array}{l}\mathrm{b} 1 \\
\mathrm{~b} 2\end{array}$ & M \\
\hline Potential number of reproduction cycles per year & $\begin{array}{l}<1 \\
1 \\
>1\end{array}$ & $\begin{array}{l}\mathrm{c} 1 \\
\mathrm{c} 2 \\
\mathrm{c} 3\end{array}$ & $\mathrm{~T}$ \\
\hline Aquatic stages & $\begin{array}{l}\text { egg } \\
\text { larva } \\
\text { nymph } \\
\text { imago }\end{array}$ & $\begin{array}{l}\text { d1 } \\
\text { d2 } \\
\text { d3 } \\
\text { d4 }\end{array}$ & $\begin{array}{l}\mathrm{T} \\
\mathrm{M}\end{array}$ \\
\hline Reproduction & $\begin{array}{l}\text { Ovoviviparity } \\
\text { Isolated eggs, free } \\
\text { Isolated eggs, cemented } \\
\text { Clutches, cemented or fixed } \\
\text { Clutches, free } \\
\text { Clutches in vegetation (endophytic) } \\
\text { Clutches, terrestrial } \\
\text { Asexual reproduction }\end{array}$ & $\begin{array}{l}\text { e1 } \\
\text { e2 } \\
\text { e3 } \\
\text { e4 } \\
\text { e5 } \\
\text { e6 } \\
\text { e7 } \\
\text { e8 }\end{array}$ & $\begin{array}{l}\text { M } \\
\text { M } \\
\text { M }\end{array}$ \\
\hline Dissemination & $\begin{array}{l}\text { Aquatic passive } \\
\text { Aquatic active } \\
\text { Aerial passive } \\
\text { Aerial active }\end{array}$ & $\begin{array}{l}\text { f1 } \\
\text { f2 } \\
\text { f3 } \\
\text { f4 }\end{array}$ & $\begin{array}{l}\mathrm{T} \\
\mathrm{M}\end{array}$ \\
\hline Resistance forms & $\begin{array}{l}\text { Eggs, statoblasts, gemmules } \\
\text { Cocoons } \\
\text { Cells against desiccation } \\
\text { Diapause or dormancy } \\
\text { None }\end{array}$ & $\begin{array}{l}\text { g1 } \\
\text { g2 } \\
\text { g3 } \\
\text { g4 } \\
\text { g5 }\end{array}$ & $\begin{array}{c}\mathrm{M} \\
\mathrm{M} \\
\mathrm{T}\end{array}$ \\
\hline Respiration & $\begin{array}{l}\text { Tegument } \\
\text { Gill } \\
\text { Plastron } \\
\text { Spiracle (aerial) }\end{array}$ & $\begin{array}{l}\mathrm{j} 1 \\
\mathrm{j} 2 \\
\mathrm{j} 3 \\
\mathrm{j} 4\end{array}$ & $\begin{array}{l}\mathrm{M} \\
\mathrm{M} \\
\mathrm{M}\end{array}$ \\
\hline Locomotion and substrate relation & $\begin{array}{l}\text { Flier } \\
\text { Surface swimmer } \\
\text { Swimmer } \\
\text { Crawler } \\
\text { Burrower (epibenthic) } \\
\text { Interstitial (endobenthic) } \\
\text { Temporarily attached } \\
\text { Permanently attached }\end{array}$ & $\begin{array}{l}\text { u1 } \\
\text { u2 } \\
\text { u3 } \\
\text { u4 } \\
\text { u5 } \\
\text { u6 } \\
\text { u7 } \\
\text { u8 }\end{array}$ & $\begin{array}{c}\mathrm{M} \\
\mathrm{M} \\
\mathrm{M} \\
\mathrm{T} \\
\mathrm{M}\end{array}$ \\
\hline
\end{tabular}


Table 1. cont.

\begin{tabular}{|c|c|c|c|}
\hline Trait & Category & Code & Predictions \\
\hline \multirow[t]{9}{*}{ Food } & Fine sediment + microrganisms & h1 & \\
\hline & Detritus $<1 \mathrm{~mm}$ & $\mathrm{~h} 2$ & \\
\hline & Plant detritus $\geq 1 \mathrm{~mm}$ & h3 & $\mathrm{T}$ \\
\hline & Living microphytes & h4 & M \\
\hline & Living macrophytes & h5 & M \\
\hline & Dead animal $>1 \mathrm{~mm}$ & h6 & \\
\hline & Living microinvertebrates & $\mathrm{h} 7$ & \\
\hline & Living macroinvertebrates & $\mathrm{h} 8$ & \\
\hline & Vertebrates & h9 & \\
\hline \multirow[t]{7}{*}{ Feeding habits } & Deposit feeder & i2 & \\
\hline & Shredder & i3 & $\mathrm{T}$ \\
\hline & Scraper & i4 & M \\
\hline & Filter-feeder & i5 & \\
\hline & Piercer (plant or animal) & i6 & \\
\hline & Predator (carver/engulfer/swallower) & i7 & \\
\hline & Parasite, parasitoid & i8 & \\
\hline
\end{tabular}

available to future trait studies in Mediterranean Basin rivers. We further assessed whether the absence of these mediterranean genera in temperate Europe, and therefore in Tachet's database, resulted from mediterranean-specific traits that did not match temperate conditions (Bonada et al., 2007a). Therefore, we performed trait comparisons of non-coded genera in Tachet's database (NEW genera) with exclusive genera found in mediterranean and temperate regions that were included in Tachet's database (MED and TEM genera, respectively). We made this analysis based on a priori hypotheses about which trait categories should be highly represented in mediterranean or in temperate regions (Table 1). The rationale behind each hypothesis mainly relates to the ability of mediterranean organisms to resist or recover from summer drought and are detailed in Bonada et al. (2007a). Thus, we hypothesized that trait categories of NEW genera should have no significant differences with MED genera and that if significant differences were found, NEW genera should have trait categories associated with mediterranean conditions. Likewise, we also hypothesized that NEW and MED genera should differ from TEM genera in a similar way (i.e., significant differences between MED and TEM genera and between NEW and TEM genera would follow similar trends to those predicted in Table 1).
Alternatively, if NEW genera do not have characteristic mediterranean traits, other factors such as zoogeography, limited dissemination ability to reach and colonize temperate Europe, or rarity could explain their absence in Tachet's database.

\section{MATERIAL AND METHODS}

NEW genera were detected by an analysis of data from 488 sites from several studies carried out in a vast Mediterranean Basin area: from Portugal to Turkey and from France to Morocco (Statzner $e t$ al., 2007; Bonada et al., 2007a, unpublished material). For Dipterans, we only considered those families with some genera included in Tachet's database or Dipteran families that were not included in the database but that we found biological information for genera. For these NEW genera, we used a fuzzy coding approach similar to the approach utilised in Tachet's database. We mainly used affinity scores from 0 to 3 ; although for precision, scores higher than 3 (as much as 5) could be used for those traits with many categories (i.e., locomotion and substrate relation and food; Tachet et al., 2002). We obtained biological information for each genus by searching through published and unpublished studies, and in a few cases, we consulted taxonomic specialists from several Mediterranean Basin coun- 
tries. We found about 80 references (available upon request) that contained useful information for trait coding of our NEW genera. We gave special attention to gathering information for the known species of each genus in order to have a wider view of genus trait plasticity. When information was not available, we scored each genus as the mean of the corresponding family scores or utilised affinity scores of a closely related taxon. In these cases, we only used the information of those genera present in at least one Mediterranean Basin country according to the Fauna Europaea Web Service (2004). For example, we used the mean of Heptageniidae genera as a surrogate for the affinity scores of Afronurus; we used the mean of Oligoneuriidae genera as a surrogate for the affinity scores of Isonychia because their larvae are similar to those of Oligoneuriidae, except for maximal size (Tachet et al., 2002). We assumed that traits at the family level were not biased because biological trait patterns are only minimally influenced by taxonomical resolution (Dolédec et al., 2000; Gayraud et al., 2003). In a few cases, we found no information on the family or on the closest taxon; we coded these trait categories as 0 .

MED genera were obtained from a database of 488 sites in the Mediterranean Basin, and TEM genera were obtained from a database of 344 sites distributed across temperate Europe. Our database has the same structure as the database described in Statzner et al. (2007) and includes all of their sites and a few others from the Mediterranean Basin. The MED and TEM databases comprised 272 and 226 genera, respectively. However, from them, we only used the exclusive genera in each database (i.e., genera present in one region but not in the other) because common genera would provide redundant information. We used fuzzy correspondence analysis (FCA; Chevenet et al., 1994) to compare the overall trait profile of MED, TEM and NEW genera. We assessed overall differences among groups of genera with a between-class analysis, a particular type of constrained multivariate analysis (see Dolédec \& Chessel, 1989; Lebreton et al., 1991). The significance of the overall difference among groups of genera (among-class variance) was tested against simulated values obtained after 999 permutations of the rows of the traitcomposition table. For each individual trait category for which we had a priori hypotheses, we applied Kruskal-Wallis rank sum tests for significant differences between NEW and MED/TEM genera. We used $\mathrm{R}$ freeware ( $\mathrm{R}$ Development Core Team, 2010) and ade4 library (Thioulouse et al., 1997; Chessel et al., 2004) to perform all statistical analyses.

\section{RESULTS}

We found 44 NEW genera and obtained 77 MED and 31 TEM genera exclusive to a particular region. Of the NEW genera, 10 belonged to Prosobranchia, and 6 belonged to Odonata and Coleoptera each. The rest of the NEW genera were distributed among Hirudinoidea, Pulmonata, Crustacea, Ephemeroptera, Plecoptera, Heteroptera, and Diptera (Table 2). We found more NEW genera in Spain (19 NEW taxa) and Morocco (12 NEW taxa). However, we also had more records from these regions (169 and 91 sites, respectively) than from any other. Interestingly, we found relatively more NEW genera in Lebanon and Israel compared with the number of records used (9 genera in 18 sites in Lebanon and 6 genera in 9 sites in Israel), but the 77 records used in south France only had 5 NEW genera.

We were able to provide complete and exclusive trait information (i.e., genera with all traits X-marked in Table 2) for only 9 NEW genera, whereas 18 genera were partly coded. We did not find exclusive biological information for 17 genera; we coded them using the mean of each corresponding family or the closest taxon (Table 2). For the genus Ochterus, belonging to the singlegenus family Ochteridae, we were only able to provide information on the "maximal size". Fuzzy-coding values for all of these non-coded genera are available in Table 3.

Overall, low but significant differences were found between MED, TEM and NEW (3.8\% of variability; simulated $P=0.001)$. The first between-class FCA axis, which explained $64 \%$ of the trait variability, separated TEM from MED 
Table 2. List of genera not included in Tachet et al. (2002) but present in mediterranean river surveys. All of these genera were coded by us using literature $(\mathrm{X})$ or as family mean or according to a closely related taxon $(=)$. For some traits and genera, we found no information on the genus or family (0). Country indicates the place where genera were recorded (AL for Algeria, CR for Croatia, FR for France, GR for Greece, IT for Italy, IS for Israel, LE for Lebanon, MO for Morocco, PO for Portugal, SP for Spain and TU for Turkey). Listado de géneros no incluidos en Tachet et al. (2002) pero presentes en muestreos de ríos mediterráneos. Todos los géneros fueron codificados por nosotros utilizando la literatura existente $(X)$ o el promedio de la familia correspondiente o de un taxón relacionado (=). Para algunos rasgos y géneros no se encontró información disponible para el género o su família (0). "Country" indica el país donde se encontaron los géneros (AL para Argelia, CR para Croacia, FR para Francia, GR para Grecia, IT para Italia, IS para Israel, LE para Líbano, MO para Marruecos, PO para Portugal, SP para España y TU para Turquía).

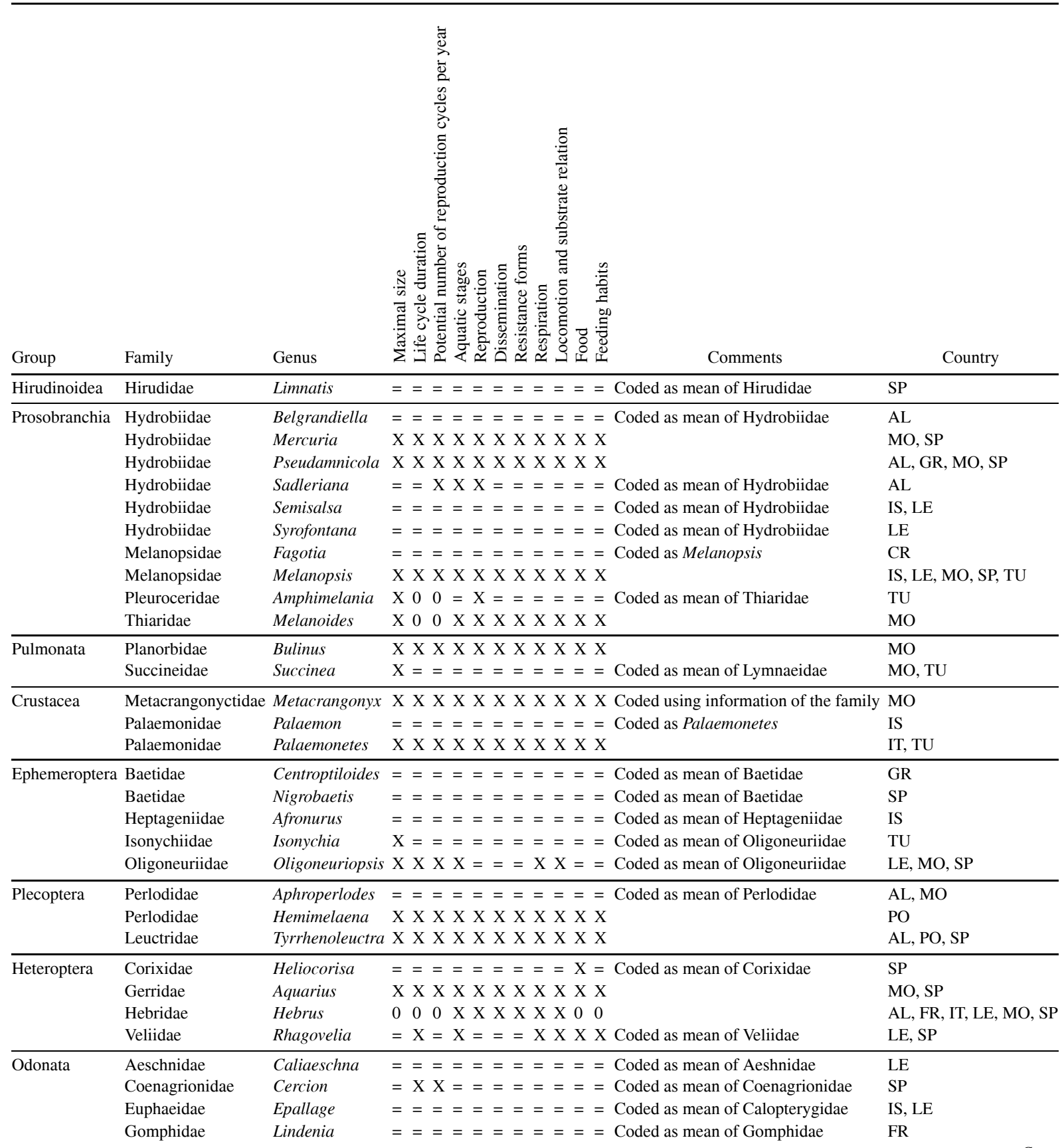




\begin{tabular}{|c|c|c|c|c|c|c|c|c|c|c|c|c|c|c|}
\hline & Family & Genus & 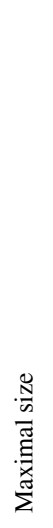 & 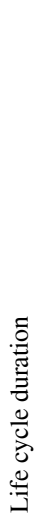 & 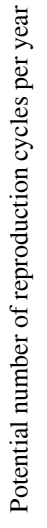 & 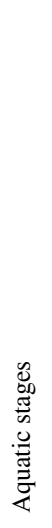 & 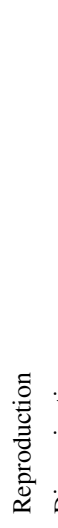 & 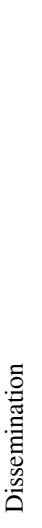 & 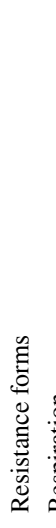 & 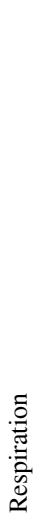 & 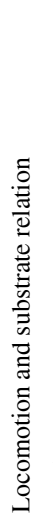 & (0) & Comments & Country \\
\hline \multirow{2}{*}{ Group } & Libellulidae & Diplacodes & $\mathrm{X}$ & $\mathrm{X}$ & $\mathrm{X}$ & $X$ & $\mathrm{X} 2$ & $\mathrm{X}$ & $=Y$ & $\mathrm{X}$ & $\mathrm{X}$ & $X=$ & Coded as mean of Libellulidae & SP \\
\hline & Libellulidae & Trithemis & $=$ & $=$ & $=$ & $=$ & $==$ & $=$ & $==$ & $=$ & $=$ & $==$ & Coded as mean of Libellulidae & IT \\
\hline \multirow[t]{6}{*}{ Coleoptera } & Dytiscidae & Canthydrus & $=$ & $=$ & $=$ & $\mathrm{X}$ & $=$ & $\mathrm{X}$ & $=y$ & $\mathrm{X}$ & $\mathrm{X}$ & $\mathrm{X} X$ & Coded as mean of Dytiscidae & SP \\
\hline & Dytiscidae & Herophydrus & $\mathrm{X}$ & $=$ & $=$ & $\mathrm{X}$ & $=$ & $\mathrm{X}$ & $=Y$ & $\mathrm{X}$ & $\mathrm{X}$ & $\mathrm{X} X$ & Coded as mean of Dytiscidae & SP \\
\hline & Elmidae & Grouvellinus & $=$ & $\mathrm{X}$ & $=$ & $=$ & $=$ & $=$ & $==$ & $=$ & $=$ & $==$ & Coded as mean of Elmidae & IS, LE \\
\hline & Hydrophilidae & Coelostoma & $=$ & $=$ & $=$ & $\mathrm{X}$ & $=$ & $=$ & $==$ & $=$ & $\mathrm{X}$ & $=\mathrm{X}$ & Coded as mean of Hydrophilidae & $\mathrm{MO}, \mathrm{SP}$ \\
\hline & Hydrophilidae & Cymbiodyta & $=$ & $=$ & $=$ & $=$ & $==$ & $=$ & $=$ & $=$ & $=$ & $==$ & Coded as mean of Hydrophilidae & $\mathrm{AL}$ \\
\hline & Ochtheridae & Ochterus & $\mathrm{X}$ & 0 & 0 & 0 & $0 \quad($ & 0 & 0 & 0 & 0 & $0 \quad 0$ & & SP \\
\hline \multirow[t]{4}{*}{ Diptera } & Athericidae & Ibisia & $=$ & $=$ & $\mathrm{X}$ & $=$ & $=$ & $=$ & $=$ & $=$ & $=$ & $==$ & Coded as Atherix & AL, FR, IT, LE \\
\hline & Blephariceridae & Apistomyia & $=$ & $=$ & $=$ & $=$ & $=$ & $=$ & $==$ & $=$ & $=$ & $==$ & Coded as mean of Blephariceridae & FR \\
\hline & Blephariceridae & Dioptopsis & $=$ & $=$ & $=$ & $=$ & $==$ & $=$ & $==$ & $=$ & $=$ & $==$ & Coded as mean of Blephariceridae & FR \\
\hline & Scatophagidae & Acanthocnema & $=$ & $=$ & $=$ & $=$ & $==$ & $=$ & $==$ & $=$ & $=$ & $\mathrm{X} X$ & Coded using information on Anthomyidae & SP \\
\hline
\end{tabular}

and NEW. In turn, MED and NEW overlapped along the first between-class FCA axis but were clearly separated along the second between-class FCA axis, which explained $36 \%$ of the trait variability (Fig. 1). We also performed betweenclass FCA using pairs of tables. Differences between MED and TEM accounted for $3.1 \%$ of the explained variability (simulated $P=0.001$ ), whereas differences between MED and NEW and TEM and NEW accounted for $2.0 \%$ and $3.2 \%$, respectively, of the explained variability (simulated $P=0.001$ ), confirming the separation observed on the first two axes of the above global FCA.

From the 31 a priori hypotheses on trait categories for MED, TEM and NEW (Table 1), 27 included enough genera to be tested for significance (i.e., more than 10 genera). When MED and TEM were compared, 8 trait categories significantly agreed with our hypotheses, 3 significantly contradicted our hypotheses, and 16 did not show significant differences (Table 4). MED and TEM genera mostly differed on the following traits: dissemination, locomotion and sub- strate relation. A comparison of NEW vs. MED genera showed that 13 categories did not have significant differences, 8 categories agreed with our hypothesis (i.e., NEW genera had significantly more mediterranean characteristics than MED genera), and 6 contradicted our hypothesis (Table 4). Thus, NEW genera significantly comprised more genera with larger maximal sizes, shorter life cycles, imago stages, ovoviviparity and diapause and ability to feed on living microphytes as scrapers. However, NEW genera were not necessarily swimmers nor did they have higher aerial active dissemination and spiracles. Comparisons between NEW and TEM genera showed that 21 categories did not show significant differences, 5 categories showed differences in agreement with our hypotheses (i.e., NEW genera had significantly more mediterranean characteristics than TEM genera), and only 1 contradicted our hypothesis. Thus, compared with TEM genera, NEW genera had smaller or larger sizes and a dominance of diapausing organisms, fliers and scrapers. 
Table 3. Biological traits (letter a-i) and their categories (number) for each genera not included in Tachet et al. (2002) but present in mediterranean rivers surveys (see Table 1 for codes of categories). Rasgos biológicos (letras a-i) y categorías (número) para cada género no incluido en Tachet et al. (2002) pero presentes en muestreos de ríos mediterráneos (ver Tabla 1 para los códigos de las categorías).

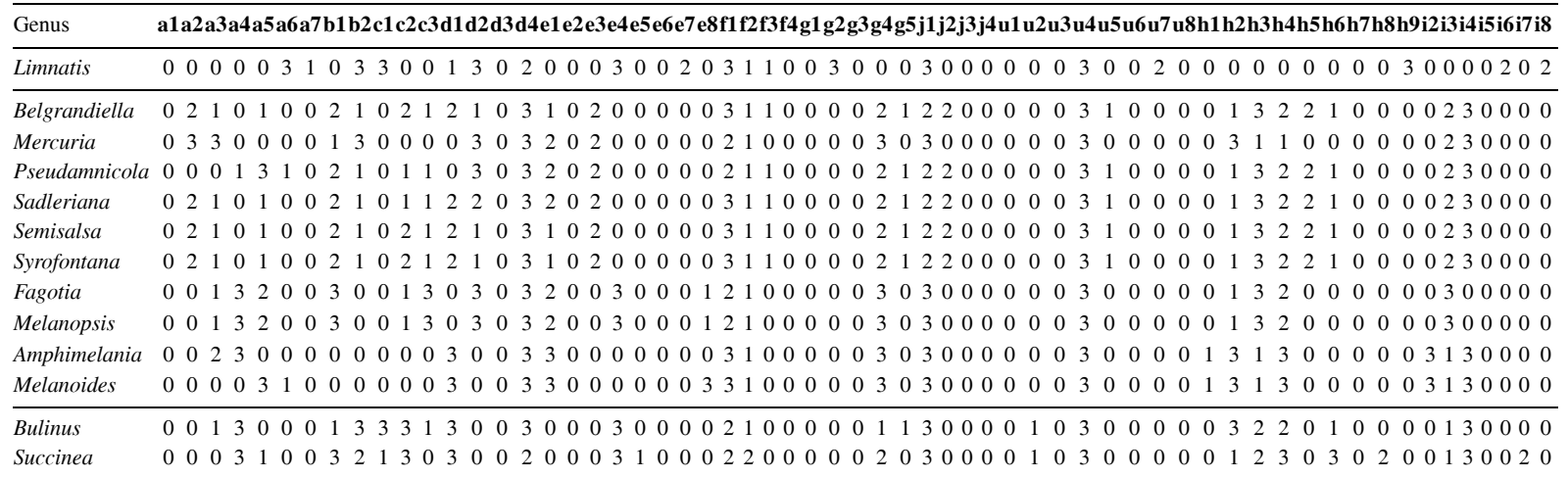

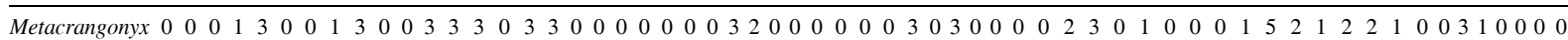

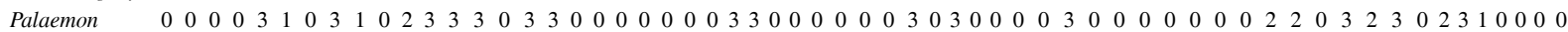

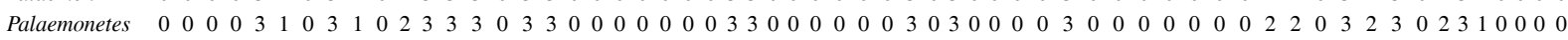

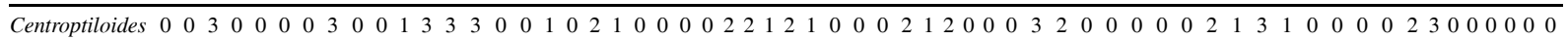

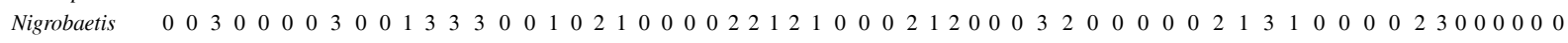
$\begin{array}{llllllllllllllllllllllllllllllllllllllllllllllllllllllllllllllllll}\text { Afronurus } & 0 & 0 & 0 & 3 & 0 & 0 & 0 & 3 & 1 & 1 & 3 & 0 & 3 & 3 & 0 & 0 & 0 & 2 & 0 & 3 & 0 & 0 & 0 & 0 & 3 & 1 & 1 & 3 & 2 & 0 & 0 & 1 & 2 & 1 & 3 & 0 & 0 & 0 & 0 & 1 & 5 & 0 & 0 & 0 & 0 & 1 & 2 & 3 & 2 & 0 & 0 & 0 & 0 & 0 & 0 & 2 & 3 & 0 & 0 & 0 & 0\end{array}$

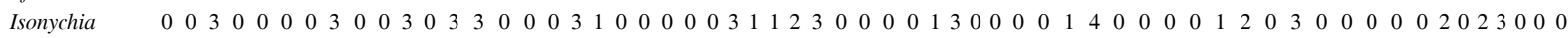

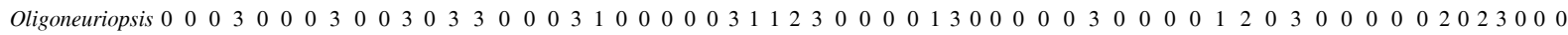

$\begin{array}{lllllllllllllllllllllllllllllllllllllllllllllllllllllllllllllllllllll}\text { Tyrrhenoleuctra } 0 & 3 & 1 & 0 & 0 & 0 & 0 & 3 & 0 & 0 & 3 & 0 & 3 & 3 & 0 & 0 & 0 & 0 & 0 & 0 & 3 & 0 & 0 & 0 & 2 & 2 & 0 & 1 & 0 & 0 & 0 & 3 & 0 & 3 & 0 & 0 & 0 & 0 & 0 & 0 & 3 & 0 & 0 & 0 & 0 & 0 & 2 & 3 & 0 & 0 & 0 & 0 & 0 & 0 & 1 & 3 & 0 & 0 & 0 & 0 & 0\end{array}$

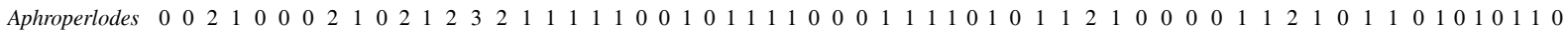

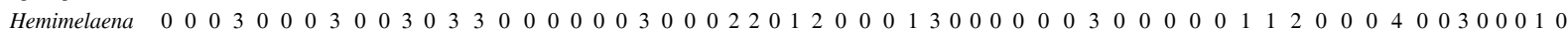
\begin{tabular}{lllllllllllllllllllllllllllllllllllllllllllllllllllllllllllllllllllllllllll}
\hline Caliaeschna & 0 & 0 & 0 & 0 & 2 & 2 & 0 & 1 & 3 & 3 & 1 & 0 & 2 & 3 & 0 & 0 & 0 & 0 & 0 & 0 & 0 & 3 & 1 & 0 & 1 & 1 & 0 & 3 & 1 & 0 & 0 & 1 & 2 & 1 & 3 & 0 & 0 & 0 & 0 & 0 & 5 & 0 & 0 & 0 & 0 & 0 & 0 & 0 & 0 & 0 & 0 & 1 & 4 & 1 & 0 & 0 & 0 & 0 & 0 & 3 & 0
\end{tabular}

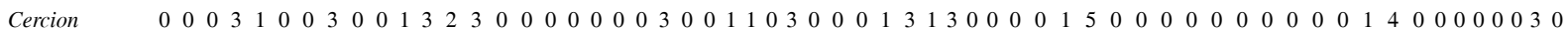

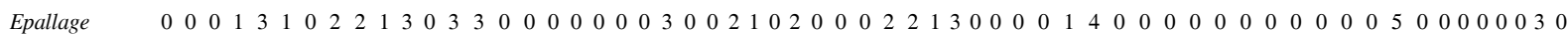

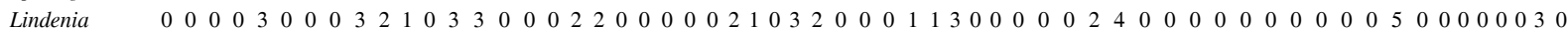

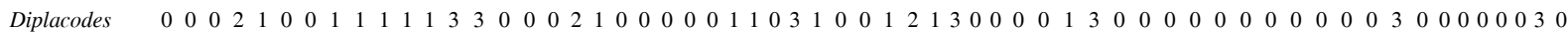

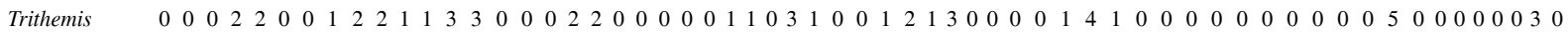

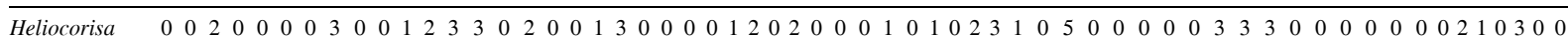
Aquarius $\quad \begin{array}{lllllllllllllllllllllllllllllllllllllllllllllllllllllllllllllllllllll}0 & 0 & 0 & 3 & 0 & 0 & 0 & 3 & 2 & 0 & 1 & 3 & 1 & 2 & 0 & 2 & 0 & 0 & 0 & 3 & 0 & 0 & 1 & 0 & 1 & 2 & 0 & 3 & 0 & 0 & 0 & 3 & 0 & 0 & 0 & 0 & 3 & 3 & 4 & 0 & 0 & 0 & 0 & 0 & 0 & 0 & 0 & 0 & 0 & 0 & 0 & 0 & 3 & 0 & 0 & 0 & 0 & 0 & 3 & 0 & 0\end{array}$

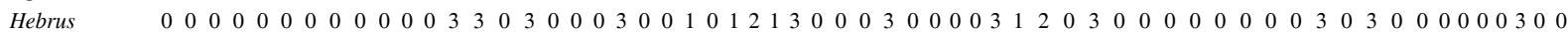

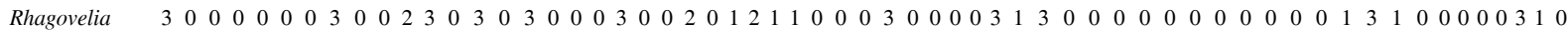

\begin{tabular}{lllllllllllllllllllllllllllllllllllllllllllllllllllllllllllllllllllll}
\hline Canthydrus & 0 & 2 & 1 & 1 & 0 & 0 & 0 & 1 & 3 & 0 & 2 & 2 & 3 & 3 & 0 & 3 & 0 & 0 & 0 & 3 & 0 & 0 & 0 & 0 & 1 & 1 & 0 & 3 & 0 & 0 & 0 & 0 & 3 & 1 & 0 & 0 & 3 & 1 & 0 & 3 & 3 & 0 & 0 & 0 & 0 & 0 & 0 & 0 & 0 & 0 & 0 & 2 & 3 & 0 & 0 & 3 & 0 & 0 & 3 & 0 & 0
\end{tabular}

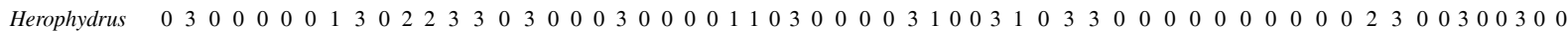

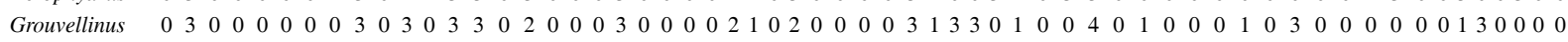

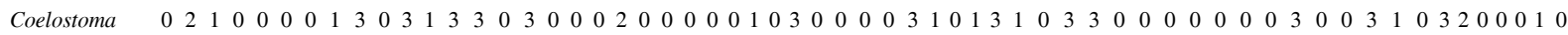

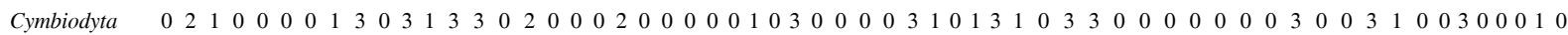
Ochterus $\quad \begin{array}{lllllllllllllllllllllllllllllllllllllllllllllllllllllllllllllll} & 0 & 3 & 3 & 0 & 0 & 0 & 0 & 0 & 0 & 0 & 0 & 0 & 0 & 0 & 0 & 0 & 0 & 0 & 0 & 0 & 0 & 0 & 0 & 0 & 0 & 0 & 0 & 0 & 0 & 0 & 0 & 0 & 0 & 0 & 0 & 0 & 0 & 0 & 0 & 0 & 0 & 0 & 0 & 0 & 0 & 0 & 0 & 0 & 0 & 0 & 0 & 0 & 3 & 0 & 0 & 0 & 0 & 0 & 3 & 0 & 0\end{array}$

\begin{tabular}{lllllllllllllllllllllllllllllllllllllllllllllllllllllllllllllllllllll}
\hline Ibisia & 0 & 0 & 0 & 0 & 3 & 0 & 0 & 3 & 1 & 0 & 3 & 0 & 0 & 3 & 0 & 0 & 0 & 0 & 0 & 0 & 0 & 0 & 3 & 0 & 0 & 1 & 0 & 1 & 0 & 0 & 0 & 0 & 3 & 0 & 1 & 0 & 0 & 0 & 0 & 0 & 3 & 0 & 1 & 0 & 0 & 0 & 0 & 0 & 0 & 0 & 0 & 0 & 3 & 0 & 0 & 0 & 0 & 0 & 3 & 0 & 0
\end{tabular}

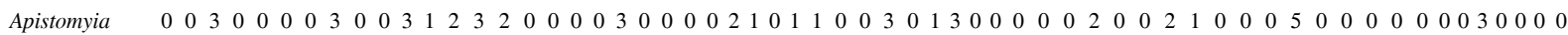

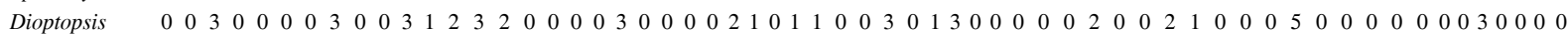

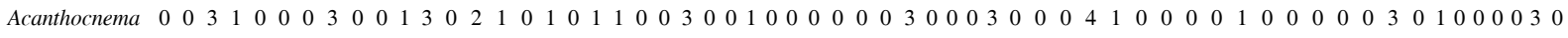

\section{DISCUSSION}

We used available literature and consulted several taxonomic specialists to code traits for 44 genera found in the Mediterranean Basin but that were not included in Tachet's database. These NEW genera belonged to different taxonomic groups; Mollusca encompassed the highest number of non-coded genera. Although Mollusca has more species in the Paleartic than in other zoogeographical regions (Strong et al., 2008), some families are recognized to have a Gondwana origin (Ponder \& Walker, 2003; Strong et al., 2008) and therefore could have been present in North 


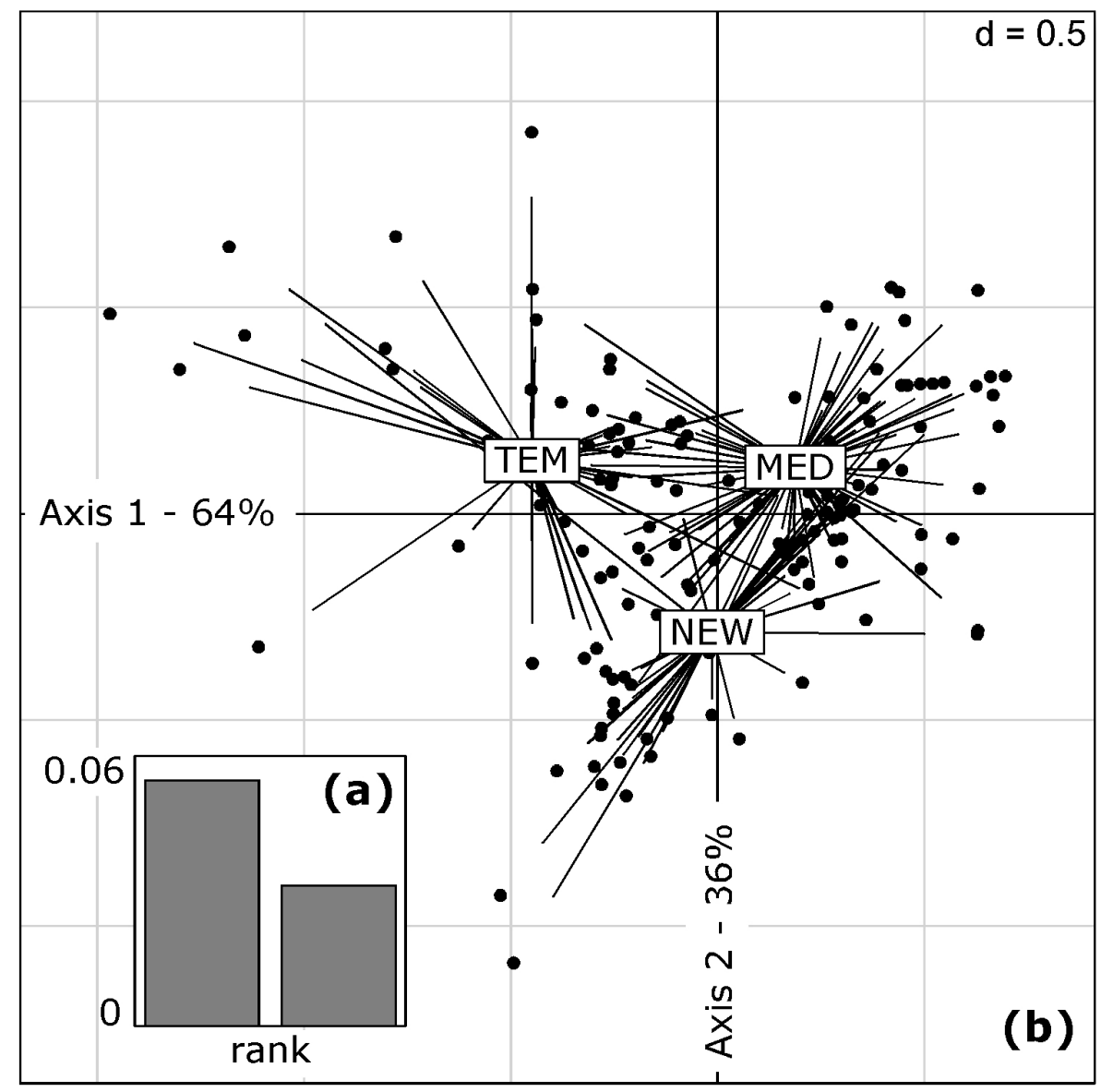

Figure 1. Result of a between-class fuzzy correspondence analysis (FCA) performed on the 11 traits-by-genera array showing (a) the histogram of eigenvalues and (b) the first two axes factorial map. Genera (dots) are linked to a given group by a line. MED for mediterranean genera, TEM for temperate genera and NEW for new-coded mediterranean genera. Resultado del análisis de correspondencias difusas entre tipos de géneros (FCA) realizado con los datos de 11 rasgos biológicos y mostrando (a) el histograma de valores propios y (b) el mapa factorial de los dos primeros ejes. Los géneros (puntos) están unidos a su correspondiente grupo con una línea. MED indica géneros mediterráneos ya codificados, TEM indica géneros de la región templada, y NEW nuevos géneros mediterráneos no codificados.

Africa for a long time. This is the case of Hydrobiidae, the family from which we found the most genera not included in the Tachet's database, and Thiaridae, for which we also found a noncoded genus in Morocco. In addition, some of these genera, such as Bulinus, are widely documented in African and Asian regions (e.g., Chu et al., 1968; Kluste \& Baleux, 1996; Laamrani \& Boelee, 2002), and their distribution is constrained to the Mediterranean Basin. However, 4 Mediterranean Basin regions appear as a hotspot for Molluscan biodiversity, and overall lower diversity has been found at higher latitudes
(Strong et al., 2008). Other taxonomic group characteristics from mediterranean rivers (Heteroptera, Odonata and Coleoptera, Bonada et al., 2007a) also contained genera not coded in Tachet's database. Interestingly, Ribera (2000) showed that the Iberian Peninsula was very rich in Coleoptera, and it is considered a hotspot of Dytiscidae. Although we used more sites from Spain than from other countries, of the 6 non-coded Coleoptera that we found, only 4 were solely present in Spain, and 2 of those were Dytiscidae.

In a previous study, we found that macroinvertebrate composition in mediterranean and tem- 
perate rivers differed in trait composition, and those differences concerned traits that were associated with higher resilience and resistance to seasonal flow variability in the Mediterranean Basin (Bonada et al., 2007a). Therefore, it is not surprising that we found similar results when analysing the trait profile of exclusive genera found in each climatic region. When significant, our trait predictions between MED and TEM genera were confirmed. According to our

Table 4. Mean affinity values expressed as the per cent of all mediterranean (MED), temperate (TEM) and new coded mediterranean (NEW) genera for each biological trait category, showing results of the Kruskal-Wallis non-parametric tests between pairs of genera types. Only traits for which we could provide a priori predictions for the mediterranean region are presented (Table 1). The term "no data" indicates that there were less than 10 genera with information for that category; therefore, the mean values and tests are not presented. The Kruskal-Wallis non-parametric test was not performed for those categories lacking enough genera (e.g., a1, a6, e8, g3, u2, u6, h5) and, therefore, is not presented. For all tests, (0) indicates that no significant differences were found. For MED vs. TEM test, (+) indicates that results follow our predictions and (-) indicates the opposite pattern. For MED vs. NEW and TEM vs. NEW tests, (++) indicates that, according to our predictions, a NEW genera has significant mediterranean characteristics for that category, whereas (-) indicates the opposite pattern. Valores de afinidad medios (en \%) de los géneros mediterráneos (MED) y templados (TEM) codificados y los no codificados (NEW) para cada categoría de rasgos biológicos, junto con resultados de los análisis no paramétricos Kruskal-Wallis entre tipos de géneros. Sólo se presentan las categorías para las que se puedieron establecer predicciones a priori para el Mediterráneo (Table 1). "No data” indica que había menos de 10 géneros con información para esa categoría y, por lo tanto, no se presentan las medias. Asimismo, para aquellas categorías con insuficiente número de genéros, no se calculó el test no paramétrico Kruskal-Wallis y, por lo tanto, no se presentan (i.e. al, a6, e8, g3, u2, u6, h5). Para todos los análisis, un (0) indica que no hubo diferencias significativas. Para el análisis entre MED y TEM, un (+) indica que los resultados siguen nuestras predicciones y un (-) el contrario. Para los análisis entre MED vs. NEW y TEM vs. NEW, un (++) indica que, según nuestras predicciones, un género NEW tiene características significativamente más mediterráneas para esa categoría, mientras que un (-) indica el contrario.

\begin{tabular}{|c|c|c|c|c|c|c|c|c|}
\hline \multirow{3}{*}{ Trait } & \multirow[t]{2}{*}{ Category } & \multirow[t]{2}{*}{ Code } & \multicolumn{3}{|c|}{ Mean (\%) } & \multicolumn{3}{|c|}{ Kruskal-Wallis Tests } \\
\hline & & & TEM & \multirow{2}{*}{$\begin{array}{c}\text { MED } \\
24\end{array}$} & \multirow{2}{*}{$\frac{\text { NEW }}{18}$} & \multicolumn{3}{|c|}{ TEM vs. MED TEM vs. NEW MED vs. NEW } \\
\hline & $>0.25-0.5 \mathrm{~cm}$ & a2 & 4 & & & $(+)$ & $(++)$ & 0 \\
\hline & $>0.5-1 \mathrm{~cm}$ & a3 & 26 & 23 & no data & 0 & & \\
\hline & $>1-2 \mathrm{~cm}$ & $\mathrm{a} 4$ & 42 & 24 & 24 & $(+)$ & 0 & 0 \\
\hline & $>2-4 \mathrm{~cm}$ & a5 & 11 & 20 & 23 & 0 & 0 & 0 \\
\hline Life cycle duration & $\leq 1$ year & b1 & 59 & 47 & 63 & 0 & 0 & $(++)$ \\
\hline $\begin{array}{l}\text { Potential number of } \\
\text { reproduction cycles per year }\end{array}$ & $<1$ & $\mathrm{c} 1$ & 19 & 14 & no data & 0 & & \\
\hline \multirow[t]{2}{*}{ Aquatic stages } & larva & $\mathrm{d} 2$ & 37 & 42 & 40 & $(-)$ & 0 & 0 \\
\hline & imago & $\mathrm{d} 4$ & 14 & 15 & 24 & 0 & $(++)$ & $(++)$ \\
\hline \multirow[t]{2}{*}{ Reproduction } & Ovoviviparity & e1 & 19 & no data & $\overline{\text { no data }}$ & & & \\
\hline & Clutches, terrestrial & e7 & no data & 7 & no data & & & \\
\hline \multirow[t]{2}{*}{ Dissemination } & Aquatic passive & f1 & 31 & 16 & 38 & $(+)$ & 0 & $(++)$ \\
\hline & Aerial active & $\mathrm{f} 4$ & 28 & 48 & 26 & $(+)$ & 0 & $(-)$ \\
\hline \multirow[t]{2}{*}{ Resistance forms } & Diapause or dormancy & g4 & 20 & 20 & 43 & 0 & $(++)$ & $(++)$ \\
\hline & None & g5 & 44 & 66 & 42 & $(-)$ & 0 & $(-)$ \\
\hline \multirow[t]{3}{*}{ Respiration } & Gill & $\mathrm{j} 2$ & 25 & 27 & 39 & 0 & 0 & 0 \\
\hline & Plastron & $\mathrm{j} 3$ & no data & 4 & no data & & & \\
\hline & Spiracle (aerial) & $\mathrm{j} 4$ & 9 & 31 & 18 & $(+)$ & 0 & $(-)$ \\
\hline \multirow[t]{3}{*}{$\begin{array}{l}\text { Locomotion and } \\
\text { substrate relation }\end{array}$} & Flier & $\mathrm{u} 1$ & 1 & 6 & 4 & $(+)$ & $(++)$ & 0 \\
\hline & Swimmer & u3 & 8 & 25 & 16 & $(+)$ & $(++)$ & $(-)$ \\
\hline & Crawler & $\mathrm{u} 4$ & 67 & 52 & 60 & $(+)$ & 0 & 0 \\
\hline \multirow[t]{2}{*}{ Food } & Plant detritus $\geq 1 \mathrm{~mm}$ & h3 & 19 & 7 & no data & 0 & & \\
\hline & Living microphytes & $\mathrm{h} 4$ & 12 & 13 & no data & 0 & & \\
\hline \multirow[t]{2}{*}{ Feeding habits } & Shredder & i3 & 31 & 36 & 26 & 0 & 0 & 0 \\
\hline & Scraper & i4 & 11 & 10 & no data & 0 & & \\
\hline
\end{tabular}


predictions in Table 1, some trait categories of NEW genera were even more mediterraneanlike that those of MED, whereas the trait categories of other NEW genera were not. Different trait combinations allow organisms to cope with specific environmental conditions. For mediterranean river ecosystems, predictable floods and droughts are major constraints for freshwater macroinvertebrates (Gasith \& Resh, 1999), and organisms can cope with them in different ways. For example, MED genera use aerial active dissemination that allows organisms to escape from a drought; NEW genera have diapause, which is also a strategy to avoid survive droughts (Williams, 2006). Interestingly, we were able to show that almost all trait categories that significantly differed between NEW and TEM genera indicated that NEW genera had more mediterranean characteristics, which agreed with our main hypothesis. Therefore, our results suggest that some biological traits for NEW genera allow them to successfully inhabit mediterranean rivers. This finding may explain why these genera have not been extensively found in temperate Europe and why they were not included in Tachet's database. However, we cannot discount other explanations. Although fliers were more frequent in NEW than in TEM genera, NEW genera had no strong aerial active dissemination, that is, the trait category f4 was significantly less frequent in NEW genera than in MED genera; therefore, NEW genera have a limited overland dissemination that may hamper their success in temperate Europe (Bohonak \& Jenkins, 2003). Additionally, the $44 \mathrm{NEW}$ genera seem to be rare in the Mediterranean Basin. Seventeen genera out of these 44 genera were only found in a single site of the 488 sites in the Mediterranean Basin (a per cent of occurrence equal to 0.2), whereas the genera that occurred most frequently were the Prosobranchia Melanopsis and Mercuria (a per cent of occurrence equal to 9.0 and 5.3, respectively). Finally, we acknowledge that not all of these genera have been exclusively found in this region, and most of them have been also recorded in temperate Europe (see Fauna Europaea Web Service, 2004). However, we did not find them in the TEM genera database, which in- cluded 344 sites scattered across Europe and covered different river types (Statzner et al., 2007). This finding may indicate that their occurrence outside of the Mediterranean Basin is also very low. Therefore, we conclude that mediterranean genera not included in Tachet's database are rare genera with low dispersal abilities but that they have some mediterranean trait characteristics that allow them to cope with drought periods. As the knowledge of the fauna in the Mediterranean Basin increases, we can expect new genera to be added to the list. Similarly, as new biological information from these new genera or from existing genera is generated, Tachet's database should be revisited, and the fuzzy coding should be modified accordingly. We encourage our Mediterranean Basin colleagues to provide information on the biological traits of all of these genera to improve our knowledge on macroinvertebrate communities and their functional characteristics.

\section{ACKNOWLEDGEMENTS}

We would like to thank Javier Alba-Tercedor, Andrés Millán, Carmen Elisa Sáinz-Cantero and Manuel Tierno de Figueroa for providing trait information of the taxonomic groups of their field of expertise.

\section{REFERENCES}

BÊCHE, L. A., E. P. MCELRAVY \& V. H. RESH. 2006. Long-term seasonal variation in the biological traits of benthic-macroinvertebrates in two Mediterranean-climate streams in California, U.S.A. Freshwater Biology, 51: 56-75.

BOHONAK, A. \& D. JENKINS. 2003. Ecological and evolutionary significance of dispersal by freshwater invertebrates. Ecology Letters, 6: 783-796.

BONADA, N., S. DOLÉDEC \& B. STATZNER. 2007a. Taxonomic and biological trait differences of stream macroinvertebrate communities between mediterranean and temperate regions: implications for future climatic scenarios. Global Change Biology, 13: 1658-1671.

BONADA, N., M. RIERADEVALL \& N. PRAT. 2007b. Macroinvertebrate community structure 
and biological traits related to flow permanence in a Mediterranean river network. Hydrobiologia, 589: 91-106.

CAVENDER-BARES, J., D. D. ACKERLY, D. A. BAUM \& F. A. BAZZAZ. 2004. Phylogenetic overdispersion in Floridian oak communities. The American Naturalist, 163: 823-843.

CHESSEL, D., A. B. DUFOUR \& J. THIOULOUSE. 2004. The ade4 package-I - One-table methods. $R$ News, 4: 5-10.

CHEVENET, F., S. DOLÉDEC \& D. CHESSEL. 1994. A fuzzy coding approach for the analysis of long-term ecological data. Freshwater Biology, 31: 295-309.

CHU, K. Y., J. MASSOUD \& F. ARFAA. 1968. Distribution and ecology of Bulinus truncatus in Khuzestan, Iran. Bulletin of the World Health Organization, 39: 607-637.

DOLÉDEC, S. \& D. CHESSEL. 1989. Rythmes saisonniers et composantes stationnelles en milieu aquatique. II. Prise en compte et élimination d'effets dans un tableau faunistique. Acta Oecologica, 10: 207-232.

DOLÉDEC, S., J. M. OLIVIER \& B. STATZNER. 2000. Accurate description of the abundance of taxa and their biological traits in stream invertebrate communities: effects of taxonomic and spatial resolution. Achiv für Hydrobiologie, 148: 2543.

DOLÉDEC, S., N. PHILLIPS, M. SCARSBROOK, R. H. RILEY \& C. R. TOWNSEND. 2006. Comparison of structural and functional approaches to determining landuse effects on grassland stream invertebrate communities. Journal of the North American Benthological Society, 25: 44-60.

FAUNA EUROPAEA WEB SERVICE. 2004. Fauna Europaea version 1.1.: http://www.faunaeur.org.

GASITH, A. \& V. H. RESH. 1999. Streams in mediterranean climate regions: abiotic influences and biotic responses to predictable seasonal events. Annual Review of Ecology and Systematics, 30: 51-81.

GAYRAUD, S., B. STATZNER, P. BADY, A. HAYBACH, F. SCHÖLL, P. USSEGLIO-POLATERA $\&$ M. BACCHI. 2003. Invertebrate traits for the biomonitoring of large European rivers: an initial assessment of alternative metrics. Freshwater Biology, 48: 2045-2064.

HENRY, P. Y., S. LENGYEL, P. NOWICKI, R. JULLIARD, J. CLOBERT, T. ČELIK, B. GRUBER, D.
SCHMELLER, V. BABIJ \& K. HENLE. 2008. Integrating ongoing biodiversity monitoring: potential benefits and methods. Biodiversity and Conservation, 17 : 3357-3382.

HORRIGAN, N. \& D. J. BAIRD. 2008. Trait patterns of aquatic insects across gradients of flowrelated factors: a multivariate analysis of Canadian national data. Canadian Journal of Fisheries and Aquatic Sciences, 65: 670-680.

KLUSTE, A. \& B. BALEUX. 1996. Survival of Bulinus truncatus and Biomphalaria pfeifferi in sewer water purified in stabilization ponds in a sudanese saharan zone. Medecine tropicale: revue du corps de santé colonial, 56: 41-47.

KÜHN, I., W. DURKA \& S. KLOTZ. 2004. BiolFlor - a new plant-trait database as a tool for plant invasion ecology. Diversity and Distributions, 10: 363 365.

LAAMRANI, H. \& E. BOELEE. 2002. The role of irrigation design and water management parameters in the ecology of transmission and control of Schistosomiasis in central Morocco. Cahiers d'études et de recherches francophores/Agricultures, 11: 23-29.

LEBRETON, J. D., R. SABATIER, G. BANCO \& A. M. BACOU. 1991. Principal component and correspondence analyses with respect to instrumental variables: an overview of their role in studies of structure - activity and species - environment relationships. In: Applied multivariate analysis in SAR and Environmental studies. J. Devillers \& W. Karcher (eds.): 85-114. Springer Verlag. Berlin. Germany.

MACLEOD, N. \& P. L. FOREY. 2002. Morphology, shape and phylogeny. Taylor \& Francis. London. UK. 308 pp.

PONDER, W. F. \& K. F. WALKER. 2003. From mound springs to mighty rivers: the conservation status of freshwater Molluscs in Australia. Aquatic Ecosystem Health \& Management, 6: 19-28.

R DEVELOPMENT CORE TEAM. 2010. R: A language and environment for statistical computing. R Foundation for Statistical Computing. Vienna. Austria.

RIBERA, I. 2000. Biogeography and conservation of Iberian water beetles. Biological Conservation, 92: 131-150.

STATZNER, B., P. BADY, S. DOLÉDEC \& F. SCHÖLL. 2005. Invertebrate traits for the biomonitoring of large European rivers: an initial as- 
sessment of trait patterns in least impacted river reaches. Freshwater Biology, 50: 2136-2161.

STATZNER, B., N. BONADA \& S. DOLÉDEC. 2007. Conservation of taxonomic and biological trait diversity of European stream macroinvertebrate communities: a case for a collective public database. Biodiversity and Conservation, 16: 3609-3632.

STATZNER, B., A. G. HILDREW \& V. H. RESH. 2001. Species traits and environmental constraints: Entomological research and the history of ecological theory. Annual Review of Entomology, 46: 291316.

STRONG, E., O. GARGOMINY, W. PONDER \& P. BOUCHET. 2008. Global diversity of gastropods (Gastropoda; Mollusca) in freshwater. Hydrobiologia, 595: 149-166.

TACHET, H., P. RICHOUX, M. BOURNAUD \& P. USSEGLIO-POLATERA. 2002. Invertébrés
d'Eau Douce (2nd corrected impression). CNRS éditions. Paris. France. 588 pp.

THIOULOUSE, T., D. CHESSEL, S. DOLÉDEC \& J. M. OLIVIER. 1997. ADE-4: a multivariate analysis and graphical display software. Statistics and Computing, 7: 75-83.

TOMANOVA, S. \& P. USSEGLIO-POLATERA. 2007. Patterns of benthic community traits in neotropical streams: relationship to mesoscale spatial variability. Fundamental and Applied Limnology, 170: 243-255.

VIEIRA, N. K. M., N. L. POFF, D. M. CARLISLE, S. R. MOULTON II, M. L. KOSKI \& B. C. KONDRATIEFF. 2006. A database of lotic invertebrate traits for North America. U.S. Geological Survey Data Series, 187: http://pubs.water.usgs.gov/ds187.

WILLIAMS, D. D. 2006. The biology of temporary waters. Oxford University Press. New York. US. $337 \mathrm{pp}$. 